\title{
The Reception of Maria Montessori's Pedagogical Theory in Pre-School Education in Interwar Poland
}

\begin{abstract}
The innovative tendency in pedagogy, called "new education", which appeared in many European countries in the first half of the 20th century, aimed at reviving schooling, the conditions of education, and the process of learning; it also set a new role for the teacher and emphasized a new approach to the child. Maria Montessori (1870-1952), an Italian physician and educationalist, was one of the representatives of "new education". Knowledge of the pedagogical theory developed by Montessori was spread in Poland through her books and the pedagogical-psychological literature of Polish educationalists, which referred to the Montessori educational concept. The purpose of this work is to present the reception of Montessori's pedagogical theory in pre-school education in 1918-1939.
\end{abstract}

Keywords: pedagogical theory of Maria Montessori, pre-school education in Poland, representatives of pre-school education in the interwar period, pedagogical journals.

\section{Recepcja teorii pedagogicznej Marii Montessori w wychowaniu przedszkolnym w Drugiej Rzeczypospolitej}

\begin{abstract}
Abstrakt
Nowatorski nurt w pedagogice, określany mianem „nowego wychowania”, który pojawił się w wielu krajach Europy w I połowie XX w., zmierzał do odnowy szkoły, warunków nauki i procesu uczenia się, wyznaczał nową rolę nauczycielowi, akcentował także nowe podejście do dziecka. Jedną z wielu przedstawicieli „,nowego wychowania” była Maria Montessori (1870-1952), włoska lekarka i pedagog. Poznaniu
\end{abstract}

* University of Lodz, Faculty of Educational Sciences, Department of the History of Education and Pedeutology.

Article Received: January 7, 2020; Accepted: March 31, 2020. 
teorii pedagogicznej M. Montessori w Polsce służyły publikacje książkowe jej autorstwa oraz literatura pedagogiczno-psychologiczna polskich pedagogów, w której nawiązywano do koncepcji wychowania Montessori. Celem artykułu jest ukazanie recepcji teorii pedagogicznej $\mathrm{M}$. Montessori $\mathrm{w}$ wychowaniu przedszkolnym $\mathrm{w}$ latach 1918-1939.

Słowa kluczowe: teoria pedagogiczna Marii Montessori, wychowanie przedszkolne w Polsce, przedstawicielki edukacji przedszkolnej w okresie międzywojennym, czasopiśmiennictwo pedagogiczne.

\section{Preliminary issues}

In the 20th century, educational systems were created and shaped in correlation with the political, economic and socio-cultural conditions of the country at that time. Transformations in the field of education usually followed periods of historical breakthroughs, as an exemplification or derivative of wider political and social changes. This was also the case after regaining independence in 1918, when conditions in the reborn Polish state arose for the introduction of changes in the field of education and unprecedented possibilities for new directions and forms of pedagogical activity opened. Important elements of the educational transformations in the interwar period were not only legal and administrative solutions related to education (including the construction of the Polish education system from scratch $)^{1}$, but, above all, the development of interest and research in pedagogical sciences, noticeable in two dimensions. One concerned the so-called new education, of a rather experimental nature, but presenting theoretical and practical experiences in the field of organization and methods of education, while the second included directions of exploration and pedagogical thought in which attempts were made to take a scientific approach to educational issues (Korzeniowska 2011: 179).

The reception of the ideas of the "new education" movement, which made a strong mark in the educational practice and pedagogical thought of interwar Poland, was helped by numerous translations of the work of its European and American representatives; Maria Montessori ${ }^{2}$ played a significant role in

\footnotetext{
1 The most important legislative provisions concerning education and upbringing in the Second Polish Republic include: Decree of February 7, 1919 on compulsory education, "Dziennik Urzędowy Ministerstwa Wyznań Religijnych i Oświecenia Publicznego" (Official Journal of the Ministry of Religious Denominations and Public Education) (hereinafter: Dz.Urz.MWRiOP) 1919, No. 2, item 2; Act of 17 March 1921 - Constitution of the Republic of Poland, "Dziennik Ustaw Rzeczypospolitej Polskiej" (Journal of Laws of the Republic of Poland) (hereinafter: Dz.U.RP) 1921, No. 44, item 267; Act of 17 February 1922 on the establishment and maintenance of public elementary schools, Dz.U.RP 1922, No. 18, item 143; Act of 17 February 1922 on the construction of public elementary schools, Dz.U.RP 1922, No. 18, item 144; Act of 11 March 1932 on the education system, Dz.U.RP 1932, No. 38, item 389.

2 Other proponents of the "new education" movement, both theoreticians and practitioners, were, among others, Ellen Key (1848-1926), John Dewey (1859-1952), Georg Kerschensteiner (1854-
} 
propagating them. The new trend in pedagogy was aimed at a radical change in the institution of the school, the conditions of learning and the learning process, as well as the role of the teacher and the vision of the pupil/child (Kupisiewicz 2012: 213-240; Sośnicki 1967: 45-49, 65-72; Śliwerski 2007: 43-48). This trend, in turn, arose from philosophical premises (naturalism, sociologism and culturalism), in which attempts were made to redefine the foundations of human upbringing and education (Drynda 2000: 36; Śliwerski 2006: 72). Without focusing on the contemporary definitions of "new education", it is worth emphasizing that this movement not only remained in opposition to the traditional school of Jan Fryderyk Herbart, criticized at that time for its authoritative and repressive education and the rigid scheme of the teacher's behaviour, which did not take into account the needs and interests of pupils, their personality and development opportunities; but, above all, its representatives conducted numerous experiments, implemented various concepts, systems, centres and plans in practice, and established educational institutions in which the most important part was the child/pupil (Sobczak 1998: 42; Kupisiewicz 1984 : 39). And in this aspect it is important to emphasize the significant contribution of the "new education" movement to the development of pedagogy in the world and in Poland. The "new school"3 was to be a place of free, creative work, where pupils would be introduced to cooperation and forms of team effort, moreover, it was to individualize the content of teaching and to teach children the ability to perceive, formulate and solve the theoretical and practical problems of everyday life. Progress in the field of psychology and pedagogy in the interwar period meant that the child began to be seen as a person from the first moments of its life, and its proper development in the first few years of existence was also associated with properly organized institutions of pre-school education. It is worth mentioning that the child's prestige in the family also increased during this period, the kind of "promotion" of childhood that followed, especially after the First World War, was manifested in many aspects of social life: in legislation, health care, science, and culture (Gawin 2014: 77-93).

\section{Pre-school education after independence}

Important postulates and concepts in the sphere of the organization of pre-school education appeared on the threshold of independence - during the Teachers' Congress held in Warsaw in April 1919. It should be mentioned that the urgent

1932), and Ovid Decroly (1871-1932), Édouard Claparède, Paweł Błoński (1884-1941), Karl Linke (1884-1938), Celestyn Freinet (1896-1966), Helen Parkhurst (1887-1959). In Poland, among others: Henryk Rowid (1877-1944), Janusz Korczak (1878 [9]-1942), Jerzy Ostrowski (1897-1942), and Maria Grzegorzewska (1888-1967).

${ }^{3}$ A wide spectrum of names: new school, work school, life, creative, or lively school, indicated an institution that was to take into account the interests of students, develop their intellect and feelings, and teach thinking and acting. 
need to guarantee pre-school children proper institutional care became a subject of discussion for educators, doctors, journalists and social activists at the end of the First World War (Wróbel 1967: 26; Miąso 1980: 99).

The intention of the participants of the aforementioned post-war congress was to develop a national education system in the new state (Jamrożek 2011: 15-16).

The issue of pre-school education was also included in the discussions. The initiators of the changes, among whom Maria Weryho-Radziwiłłowicz, the head of the Pre-school Education Department at the Ministry of Religious Denominations and Public Education, led the way, recommended, first of all, connecting nurseries with schools, so that pre-school education institutions would be given the status of institutions preparing children for school education, and secondly, the introduction of compulsory schooling, along with the obligation for children to attend nursery school for at least the last two years before the age of seven. However, the progressive demands of the congress remained only in the declarative phase, and the pre-school education project formulated in this shape was not implemented at that time. The matter of organization of pre-school education in the Second Polish Republic returned after more than a decade, as it was among the legal regulations related to the reform of education. In the light of the Act on the system of education of March 11, 1932, childcare institutions for those aged 3-7 adopted the official name "przedszkole" (pre-school), and qualification and vocational requirements were laid down for teachers (formerly minders). However, the planned, quantitative and qualitative development of pre-school education institutions could not be fully implemented, as the legislation did not specify the principles of establishing such institutions and their financial security, which are so important for their functioning. Research on this issue in relation to interwar Łódź indicates that the level and direction of development of pre-school education was mainly determined by the local government, and among the entities running nurseries/pre-schools, apart from the municipal authorities, there were still social and charity organizations, parishes and religious communes, religious assemblies, factory boards, political organizations and private individuals (Sosnowska 2014).

Legislative gaps and economic difficulties related to the economic crisis of the 1930s did not stop the progressive changes taking place in the educational space of the pre-school under the influence of the ideas of "new education". Admittedly, there was a slight shift in priorities during the aforementioned economic deadlock - pre-school institutions, implementing state and local government assistance programmes, became a place for the regular feeding of children, guaranteeing them social care; but even then the implementation of new educational concepts into educational practice was not halted. The period of shaping the theoretical

\footnotetext{
${ }^{4}$ In 1917 and 1918, during the I and II Teachers' Congresses, the basic tasks of nurseries were defined, treating them as care facilities, as well as educational institutions preparing children to study at school. The importance of nursery as an institution of the first stage of education in the concept of the three-level school system and the seven-grade elementary school was emphasized.
} 
foundations of pre-school education and determining the directions and the level of educational and didactic work of pre-school institutions - based on the achievements of developmental psychology and the aforementioned pedagogical concepts, mainly of Montessori and Decroly - came at the turn of the 1920s and 1930s. The transformations in this area were undoubtedly due to translations of the work of the above-mentioned authors, as well as native pedagogical journals, especially those addressed to pre-school teachers. It is in this type of periodical that the authors (mainly pedagogues, teachers, and doctors), publishing articles illustrating the work of pre-schools from abroad, tried to propagate new ideas and show the possibilities of innovative solutions (Sosnowska 2016b; Samsel 2003: 519-523). They opposed traditional methods based on coercion and discipline, which were then present in pre-school institutions. It was proposed to leave children greater freedom, pay attention to their interests, and help in their development (Sośnicki 1967: 45-49; 65-72; Kabzińska 2002: 21-49). An example is the magazine "Wychowanie Przedszkolne" (Pre-school Education), the editors of which, in the new issue of the magazine in 1926, informed the readers of the extension of the periodical's range by including in their pages information about new methods of educational work (Od Redakcji: 1).

\section{The pedagogical theory of Maria Montessori ${ }^{5}(1870-1952)$}

In the light of Ewa Łatacz's research, the pedagogical theory of Montessori, an Italian doctor and educator, is a set of logically related statements about education, developed by her, scientifically based on multidirectional studies, and verified during many years of pedagogical practice in institutions called children's houses (Łatacz 1996: 7). The author of the concept herself wrote: "The pedagogical theory was associated with a bold decision to introduce changes to the educational system. Children's houses spread rapidly around the world, despite the many difficulties caused by the outbreak of war [1914], and prejudice" (Montessori 2014: 41). The theory has psychological, philosophical, anthropological and sociological foundations, which became the subject of thorough analysis undertaken by researchers representing various scientific centres interested in the Montessori conception (Łatacz 1995a, 1995b; Miksza 2010; Guz 1994; Surma 2008). For the purpose of this sketch, intended to show the reception of Montessori's pedagogical theory in the field of pre-school education in the interwar period in Poland, the focus is on three aspects: the concept of child personality development, the essence of the "prepared environment" and her pedeutological views.

According to Montessori, a child develops as a biological being, but primarily exists as a psycho-spiritual being in a specific environment of human culture. Just

\footnotetext{
${ }^{5}$ Biography of the life and activities of Maria Montessori (Miksza 2010: 101-110; Łatacz 1995b: 45-61).
} 
as in the biological sense no one can grow for a child, so spiritually the child "builds" its own interior (Miksza 2010: 25). In the development of every child, the internal factor is crucial, while the environmental factor is - "secondary to life: it can change, help or destroy, but never create. The sources of development are internal" (Montessori 2014: 59). Montessori distinguished four stages in the life of Man. The first is early childhood (from birth to six years), the second - late childhood (from six years to twelve), the third - adolescence (from twelve to eighteen), and the fourth is the stage of maturity (after eighteen). In the first and third stages, the child deserves special care due to the importance and dynamics of developmental changes, while the first and second stages the author called a period of special sensitivity (Surma 2008: 43). She believed that from the moment of birth the child is shaping its own personality, and despite the fact that the newborn's mental sphere develops in an unconscious way, in the first year of existence it builds an internal image of itself and the surrounding reality. As already mentioned, in each child there is a specific, proper, psychological and spiritual growth plan, therefore education should consist in the adults (parents, educators, minders) observing the child and helping in the development process, not creating predetermined goals, and as a result - "moulding" or "forming" the child. This approach became the focal point of Montessori's pedagogical ideas, in which the child itself and its development in the most educationally favourable conditions were important. Education was to support children from birth and help in their individual development, but the essence of education is to lead the child to become independent of adults, responsible and full of love for the world (Miksza 2010: 23, 43). A child in Montessori's pedagogy is a free, uninhibited and independent unit (Montessori 2005: 61). Effective pedagogical activities would help young children on the road leading to independence. However, help should be given discreetly and gently, in accordance with the request once addressed by the child to an adult: "Help me do it myself". Supporting independence means supporting efforts during everyday activities such as walking, running, dressing, eating meals and picking up fallen objects.

Montessori paid a lot of attention to the proper arrangement of institutional space, such as a nursery, pre-school, or school. In her publications, she published tips on how to organize rooms, equipped with the necessary furniture, appliances and everyday objects adapted to the child's height, aesthetically and directly accessible (Montessori 2005: 52-53).

When we talk about the environment - she wrote - we mean everything that a child can freely choose in it and use as much as it wants. (...) The teacher does nothing but help it at the beginning in orienting itself between many different subjects and in learning how to use them properly, that is, initiating them into an ordered and active life in the environment. Later, he leaves the child free to make choices and in the performance of the work (Montessori 2014: 61). 
The "prepared environment", consisting of all the material and didactic facilities and covering the principles and forms of education, was primarily to enable children in self-education and self-development. A special role in the "prepared environment" was played by development material - a set of teaching aids specially developed empirically by the creator of the theory ${ }^{6}$. Montessori divided them into several groups: for practical life exercises, sense training, mathematics education, language education, education into the culture of life, truth and love; and for religious education (Łatacz 1995a: 25). The developmental material was characterized by simplicity, precision and the aesthetics of performance, it also took into account several principles: grading of difficulty, adaptation to the child's development needs, logical coherence of thematic links and limitations (a given type of developmental material was present only in one copy). Among the many exercises that the children performed using the developmental material, the exercises supporting the development of the senses: sight, hearing, smell, taste and touch were particularly important. According to Montessori, the development of the senses was closely related to intellectual development, and through polarization and normalization - with the integration of the whole personality of the child.

In relation to the teacher/tutor, Montessori formulated many requirements, both external in nature, e.g. proper preparation for the profession, but also internal in nature, related to spiritual development, shaping character and possessing appropriate personality traits. The personality model of the educator she outlined in special "commandments" regarding ethical and moral attitudes towards the child (Miksza 2010: 85-86). The teacher, prepared for pedagogical work, was in the Montessori concept, the second - next to the educational environment - pillar of education (łatacz 1995a: 21). The creator of the theory expected the teacher to understand the sense of pedagogical work, the essence of upbringing and education, shift the emphasis from teaching, i.e. giving knowledge, to learning, and thus independent acquisition. "In our method", she explained, "we are dealing with a radical transfer of activity that was previously associated with the teacher and is now left to the child" and: "The teacher teaching according to old methods has been replaced by the sum of many complex factors. This means that together with the teacher, many developmental materials co-exist that collaborate in educating the child" (Montessori 2014: 132). Montessori warned against watching over the pupils in activities and tasks, because unnecessary help may cause the

\footnotetext{
6 The developmental material included four elements: anthropological, psychological, educational and didactic. The first resulted from Montessori's philosophical views, the aids were constructed in such a way as to mediate the transmission of a harmonious and disharmonious picture of reality; the psychological element corresponded to sensitive cycles appearing in the child's mind, provoking the polarization of attention (specific focus on action) enabling physical and psycho-spiritual development; the educational element of the material "facilitated" the child's self-education through independent implementation of exercises; the didactic element is the transfer of knowledge about reality, i.e. the key to the world.
} 
disappearance of natural activity in physical and mental development. The educator who put Montessori's theory into practice also accepted his own obligations, including character development, spiritual formation and reflection. In addition to theoretical knowledge, the educator should have appropriate qualities, such as patience, "wise reserve", self-control, calmness, modesty and responsibility for the child's development, resulting from the internal moral attitude of the pedagogue (Surma 2008: 66). The most important quality of a teacher should be love; which was to cover not only children and adults, but all creatures. Beyond that, living in truth and humility, which enabled the educator to maintain an attitude of respect for the child, authenticity and naturalness (Łatacz 1996: 106).

\section{Reception of Montessori's pedagogical theory in interwar pre-schools}

The reception of Montessori's pedagogical theory included, on the one hand, the process of its penetration into the broadly understood educational environment, and, on the other, the process of assimilating theoretical assumptions and implementing them into educational practice by teachers and educators. According to Ewa Łatacz's research (Łatacz 1996: 167), the Montessori theory reached the Polish lands in 1912 thanks to psycho-pedagogues gathered around the Polish Society for the Research of Children (Bogdanko, Kowolik 2007: 20-32), while a wider interest in the concept of the Italian doctor and pedagogue appeared after 1913, when the Polish translation of her book: Il metodo Della pedagogia scientific applicato all'educazione infantile nelle Casa dei Bambini (The Method of Scientific Pedagogy Applied to the Education of Children in the Children's Houses) ${ }^{7}$. The popularization of a Polish textbook "Idea wychowania przedszkolnego. Casa dei Bambini jako szkółka wszechstronnej pracy dziecka” (The idea of pre-school education. The Children's House as a comprehensive work school for children), by the psychologist Ida Maria Schätzel (Schätzel 1919), was an attempt to assimilate Montessori's pedagogical concepts into Polish pre-school pedagogy. Another psychologist, Felicja Pinesowa, also had a considerable role in the process of spreading the new theory. In 1931, she published the book System wychowawczy $d r$ Marji Montessori (The educational system of Dr. Maria Montessori) (Pinesowa 1931), in which she analysed the Montessori educational system and presented polemical arguments related to it. In the publication, she also discussed the issue of fun and freedom in education and the Montessori method of reading and writing.

\footnotetext{
7 Before the war, there were numerous reviews of this publication, including by such authors as: C. Bańkowska, M. Bienenstock, A. Grudzińska, J. Joteyko, H. Koźniewska, H. Orsza-Radlińska, A. Szycówna, Z. Ziembiński - in the magazines: "Nowe Tory", "Wychowanie w Domu i Szkole”,"Ruch Pedagogiczny”, “Dziecko” and others.
} 
Deeper analysis of the Montessori theory in pre-school education was also conducted by Sergiusz Hessen, a Polish-Russian pedagogue and philosopher. In the work Podstawy pedagogiki (Foundations of Pedagogy), published in Polish in 1931, he characterized the existing pre-school education, and against this background presented the main assumptions of the Montessori method, describing in detail the didactic material and prepared surroundings in a children's house (Hessen 1997b: 125-161). In turn, in a publication from 1939, entitled $O$ sprzecznościach i jedności wychowania (On contradictions and unity of education), he criticized Montessori's views, also regarding her negation of play - the main activity of a pre-school child and the focusing of activity on action/work (Hessen 1997a: $77,232,260-262$ ). It is worth mentioning that Łatacz described Hessen as a leading critic of the Montessori theory (Łatacz 1996: 94). A little earlier, in 1935-1936, in the magazine "Przedszkole", Hessen referred to the Montessori theory of pedagogy in a series of articles: Pedagogika Marii Montessori i jej losy (The pedagogy of Maria Montessori and its fate) (Hessen 1935/1936).

However, in the interwar period, the dissemination of Montessori's pedagogical achievements was mainly due to Polish pre-school teachers, as its main recipients, both in theory and in practice. At that time, Warsaw was a significant reception centre, but so were Lviv, Łódź, Kraków, Lublin, Poznań, Częstochowa and Sosnowiec. Among the popularizers of the Montessori pedagogical concept related to the pre-school education environment were: Maria Weryho-Radziwiłłowicz, Stefania Marciszewska-Posadzowa, Aleksandra Gustowiczówna, Janina Pawłowska, Zofia Żukiewiczowa, Antonina Winiarzowa, Zofia Bogdanowiczowa, Natalia Barskaulska and Natalia Maria : 24, 167).

Aleksandra Gustowiczówna was the first graduate of the course organized by Montessori in Rome in 1914 - she participated in it on behalf of the National School Council, District and City Council of Lviv (Wróbel 1967: 23) - and was influential in the process of spreading the theory; she was also a co-author of Podręcznika dla ochroniarek (The Minder's Handbook), published in Lviv in $1920^{8}$. Undoubtedly, Janina Pawłowska, representing the Łódź centre of pre-school education, who completed the Montessori course in England, also played a significant role. Gustowiczówna published a comprehensive article on the subject of the Montessori course and pedagogical theory, in "Czasopisma Pedagogicznego" (The Pedagogical Journal), which soon provoked much discussion and was cited many times (Gustowiczówna 1918: 176-212). In it, she presented the appearance of the Montessori institution and the course of activities/lessons, and described the way teachers and children worked. She mentioned that what prevents the full implementation of the Montessori method in Poland is the lack of professional teaching aids.

\footnotetext{
${ }^{8}$ It was a collective work edited by the Pre-School Education Section of the Polish Pedagogical Society, in cooperation with S. Progulski, I. M. Schätzel, B. Żulińska, J. Warchałowska, and M. Sariusz-Jaworska.
} 
Pawłowska played an important role in the process of introducing Montessori's theory into pre-school practice in Łódź. In 1928, she began working as the head of the Pre-school Education Department in the Department of Education and Culture of the City of Łódź (Sosnowska 2016a). Above all, she tried to raise the level of educational and didactic work of municipal pre-school education institutions, but she did not neglect other pre-schools run in Łódź by social organizations. Bearing in mind the need to improve the professional skills of educators and standardize the level of pedagogical work in Łódź pre-schools, in the years 1928-1930, Pawłowska organized free 140-hour further training courses, in which over 60 educators at municipal and social pre-schools participated (Prace samorzqdu... 1931: 668 ). As part of the training, in accordance with the guidelines of the Ministry of Religious Denominations and Public Education, she introduced students to the Montessori pedagogical theory. It is worth mentioning that the ministry officially approved the Montessori method in state seminars for minders/pre-school teachers, in 1929 (Czerwiński 1929/1930: 6). She was particularly careful about the consistent introduction of these principles in pedagogical work, she emphasized the importance of the "new role" of the teacher, as well as the "new view" of the child, i.e. respecting its individuality and enabling it to develop freely. She also tried to equip the facilities with teaching aids (including Montessori development aids), furniture adapted to the height of children and equipment necessary to conduct educational activities. Pawłowska, as a member of the Łódź Section of Pre-school Educators in the Polish Teachers' Union, published in the journal "Przedszkole", created in 1933, showing the achievements of preschool education in Łódź (Pawłowska 1935/1936a: 198-199; 1935/1936b: 135; 1935/1936: 163).

One of the greatest pioneers of pre-school education was Maria Weryho-Radziwiłłowicz, who disseminated the Montessori theory of pedagogy in the Second Polish Republic by making available to educators (theoreticians and practitioners) the periodical she founded "Wychowanie Przedszkolne" (Pre-school Education $)^{9}$, as well as presenting the basis of the theory in the textbook Metodyka wychowania przedszkolnego (Methodology for pre-school education). It was here that she presented to educators both the positive and negative sides of the Italian method, noting that it should not be used uncritically in Poland (Weryho-Radziwiłłowiczowa 1931: 67). She wrote about the developmental material:

Dr. Montessori in the book "Children's Houses" discusses a rich collection of learning aids for sensory exercises. However, considering that it is quite

\footnotetext{
9 "Wychowanie Przedszkolne. Czasopismo poświęcone sprawom wychowania dzieci w wieku przedszkolnym" (Pre-school education. A journal devoted to the education of pre-school children) was a typical specialist periodical addressed to pre-school teachers. It was published regularly for 15 years, in the period January 1925-August 1939 and was the longest running periodical on issues of pre-school education in the interwar period.
} 
one-sided and quite expensive, we think that it will be useful to use aids that every educator can make by hand and which are more closely related to the child's life (Strzemeska, Weryho 1920: 213).

Weryho-Radziwiłłowicz collaborated with the "Przegląd Pedagogiczny" magazine, in which she had her own column, followed by an addendum: Fun and activities for pre-school children. Here she wrote about the educational methods of Montessori and Decroly, including a comparison of the didactic aids they developed.

The editors of the aforementioned "Wychowanie Przedszkolne", working under the direction of Weryho-Radziwiłłowicz, tried to bring pre-school practice closer to the principles of exercises in the Montessori developmental material. A special role was assigned to the exercise of the child's senses, as evidenced by many articles in the field of theory and methodology of pre-school education (Darewska 1925: 24-25; Mackiewiczówna 1926: 11-12; Ćwiczenie zmysłów 1925a: 29-30; Ćwiczenie zmysłów, 1925b: 30). The published texts indicated how the new methodological solutions could be used in Polish pre-schools. Views on the pedagogical system of Montessori were expressed in this journal magazine by, among others, Zofia Bogdanowiczowa, a student of Weryho-Radziwiłłowiczowa, and Maria Uklejska (Bogdanowiczowa 1928a; 1928b; Uklejska 1932). Uklejska encouraged the tutors to ensure that "exercises from practical life become an introduction to the talks, so willingly and often conducted in the Polish pre-school" (Łatacz 1996: 127).

Another periodical addressing the pre-school environment, in which new concepts and methods of pre-school education in the world were consistently propagated, was "Przedszkole" - an organ of the Section of Pre-school Education of the Polish Teachers' Union ${ }^{10}$. The subject of reflection, in addition to the concepts of Montessori and Frederick Fröbel, was the educational methods of Róża and Karolina Agazzi, Decroly, and Petersen. The chairwoman of the Educators' Section was Zofia Żukiewiczowa, a well-known and respected pioneer of the modern preschool education movement in Poland, author of numerous publications including theoretical and methodical articles. In the interwar period she was the head of local government pre-schools in Warsaw. She took part in pedagogical congresses and exhibitions abroad (among other places in Geneva and Paris), so she was able to keep up-to-date on the latest world achievements in the field of pre-school education. She spoke several times about the methods of education of Fröbel and Montessori, comparing their ideas (Żukiewiczowa 1935/1936a; 1935/1936b; 1935/1936c; 1935/1936d).

\footnotetext{
10 The journal "Przedszkole" was published in 1933-1939. The periodical edition coincided with new legal and administrative regulations defining the place of pre-school and teachers in the education system of the Second Polish Republic.
} 
A supporter of the Montessori theory of education was Antonina Winiarzowa, a Krakow teacher and member of the School Committee of the Association of Polish Folk Teachers (Wróbel 1967: 30). References to Montessori's theory can be found in Winiarzowa as early as 1918. In "Ruchu Pedagogicznego" (The Pedagogical Movement), she published her article Pierwsze lata polskiego dziecka (The first years of a Polish child), in which she expressed approval for the new educational system.

Montessori's book - Winiarzow wrote about "Children's houses" - is in pre-school education a real breaking down of the walls so far obscuring how to carefully and skilfully shape the senses with the help of uncomplicated instruments, facilitating the child's control, self-education, stimulating observation and independence by removing the excessive care which nips creative abilities in the bud, by helping with free development (Winiarzowa 1918: 184).

Educators in Polish pre-school institutions were particularly interested in new organizational solutions in the field of arranging the pre-school rooms, equipping them with teaching aids, and methodical work with pupils. Examples of Montessori's pedagogical theory applied in practice could be found in the publications already mentioned and other representatives of pre-school education. It was thanks to the implementation of the proposed innovative solutions into practice that it was possible to receive this theory on the ground in Polish preschools in the interwar period.

Gustowiczówna, who visited the children's house run by Montessori in Rome in 1914, drew attention to the equipment of pre-school facilities adapted to the needs of children. At that time, she observed high-ceilinged, spacious and well-lit rooms:

One of them is all glazed, with the door open to a carefully maintained garden, where children have their own flower beds, and care for flowers and plants. The arrangement of the room consists of small tables (light, for 2-3 children, in several sizes, fitted to height), light chairs, blackboards, a large table, with a rug on the floor in front of it, a giant vermillion ellipse marked on the stone floor, a piano in the corner, low cupboards from which a child can easily take utensils, a picture of the Madonna on the wall, low tables in front of the windows, with toys, a lot of plants and flowers (Gustowiczówna 1918: 177-178).

Information about the functionality of the pre-school room was included in a publication by Marciszewska-Posadzowa - Z metodyki wychowania przedszkolnego (From the methodology of pre-school education). "Montessori", she wrote, "arranges her «Children's house» so that there would be the possibility to move 
tables and stools freely, and for a child to do so" (Marciszewska-Posadzowa 1924: 31). In turn, Weryho-Radziwiłłowiczowa proposed replacing the large, heavy school bench with a light table and easy-to-move chairs. She also drew attention to the need to adapt the appearance of pre-school rooms to resemble the interior of a family home, thanks to the introduction of, among other things, paintings, flowers and aquariums that give rooms a cosy character (Weryho-Radziwiłłowiczowa 1931: 64). Żukiewiczowa noted that all the items in the children's house, such as cupboards, hangers, sweeping brushes, watering cans, should be appropriate in size and weight for the child (Żukiewiczowa 1935: 10). Thanks to an environment prepared in such a way, the child has the opportunity to become independent, willingly uses various objects and does not need the help of adults. Similar conclusions were drawn in one of her articles on pre-school education by Uklejska (1932: 4). Methods of exercises with Montessori developmental material, being the equipment of pre-school rooms, were presented in many publications. Pre-school educators often suggested modifying Montessori aids, mainly due to the limited financial resources available at that time in pre-schools. Many educatorpractitioners independently created teaching aids similar to the Montessori development material, which should be considered as an additional element in popularizing the Montessori method.

Pedeutological views formulated by Montessori were also a basis of analysis in Polish pedagogical and psychological publications of the interwar period. This issue was analysed, among others by Gustowiczówna, Żukiewiczowa, and Natalia Cicimirska. Cicimirska wrote about the subtle relationship of a teacher with a child in the process of education:

The teacher's role is limited to care and discreet management. (...) During a short, concise and simple lesson, the teacher's person disappears, and only the subject to which we want to draw the child's attention remains visible. The educational skill consists mainly in limiting - if possible - the active intervention and help of the manager [tutor] (Cicimirska 1928: 19).

In the light of Montessori's views, the pre-school teacher helped "as much as necessary - as little as possible" (Łatacz 1996: 107). Therefore, the teachers' interference during their wards' activities was to be adapted to the child's needs at a given moment in order to provide it with the conditions for optimal development. "The task of the educator - wrote Cicimirska - is not to confuse motionlessness with something positive, and movement with something negative; our goal is to educate in movement, work, the good, not to lead towards calmness and passivity" (Cicimirska 1928: 19). Gustowiczówna pointed to the teacher's internal and spiritual preparation: "The teacher is silent. More and more focused, it looks as if she were saying a prayer before starting work" (Gustowiczówna 1918: 177). Żukiewiczowa, on the other hand, emphasized the responsibility of the role of teacher-educator, but also pointed to the importance of love in pedagogical work. 
For the development of the child's intelligence - she wrote - we have many objects, colours, shapes, etc., but for the development of the spirit, we ourselves are the object for the child. Children's pure souls should draw nourishment from us, they should look at us with all their heart so that they can rise up in their deepest spiritual development by loving us (Żukiewiczowa 1935/1936c: 149).

According to her, the requirements for an educator should be not only "excellent pedagogical and psychological preparation, but also perfect self-mastery and deeply intelligent orientation, at which moment to behave actively" (Żukiewiczowa 1935: 14). As Schätzel emphasized, Maria Montessori herself wrote about the teacher: "We have been learning educational methods since we were children; with the help of a child - and through a child - we can gradually improve the theory and practice of education" (Schätzel 1919: 45).

Although the aforementioned books and journals served to teach about Montessori's theory of pedagogy (including her educational methods), the participation of teachers in various forms of professional development, such as courses, training sessions, and pedagogical conferences, and participation in occasional meetings, such as exhibitions, shows, readings, lectures, children's weeks, was also of great significance in the reception of the theory in the years 1918-1939, in the context of its dissemination in Polish pre-school institutions. For practitioners, these were very important, because they enabled the acquired patterns and skills to be implemented in specific pedagogical work. An example of a form of popularizing the Montessori theory outside of publications is the Wystawa Wychowanie Przedszkolne (Pre-school Education Exhibition) organized for several days (April 6-11, 1926) in Warsaw during the Congress of the Society for Preschool Education, which presented a way of working with children based on the new methods of education. The exhibition covered several sectors: the didactic and methodological, children's creations, pre-school facilities, and the statistical and administrative (Sprawozdanie z Wystawy 1926). In the first of these, didactic aids from several pedagogical systems were collected: those of Montessori, Decroly, Claparède and Desceudres, and Warsaw pre-school teachers presented specific exercises based on innovative methodological solutions in working with pre-school children. "Children's Week", organized in major cities in Poland, on September 15-23, 1928, presented a special opportunity to learn non-traditional methods of upbringing and education (W.S. 1928). At that time, the addressees of many activities in the area of pre-school education were not only educators who visited exemplary educational institutions, but also children, parents and siblings. Lectures, press publications, radio programmes, and poster sessions were organized then, and for children - games in gardens, parks, playgrounds and common rooms. In turn, during the 6th Congress of the International League of New Education, held from July 29 to August 12, 1932 (Międzynarodowy Kongres 
1932), in addition to issues related to upbringing and education broadly understood, attempts were made to popularize innovative methods of education adopted in various countries (through readings, lectures and meetings).

\section{Conclusion}

Łatacz lists several stages of the reception of Montessori's pedagogical theory in Polish pre-school institutions of the interwar period, and combines this phenomenon with the publishing and practical activities of pre-school educators (Łatacz 1996: 167). Journals played a major role in the popularization of Montessori's educational thought, among which periodicals related to pre-school education, such as "Wychowanie Przedszkolne" and "Przedszkole", played an important role. Scientific publications in the field of psychopedagogy and methodology were another source from which knowledge about the pedagogical ideas of the Italian doctor and pedagogue was obtained in Poland, as were also various forms of further education and professional development. Warsaw was the main reception centre. Gustowiczówna and Marciszewska-Posadzowa had direct contact with Montessori, and tried to transfer elements of her pedagogy into the Polish theory of pre-school education. Interest in the Montessori concept grew in the years 1920-1929; many pre-school textbooks were published at that time, in which issues related to the pedagogical theory of Montessori were raised. The next period (1930-1939) saw - along with the acceptance of its views, the implementation of its ideas for pre-schools, and the definitive definition of the place of Montessori theory in Polish pre-school education - also critical voices from the educational environment. It is worth noting that the reception in Poland did not concern the entire Montessori theory, it focused mainly on its methodological solutions, bypassing the anthropological assumptions. It came at a time of difficult political, economic and social conditions in the Second Polish Republic, and yet, thanks to the enormous commitment of the pre-school education community, it managed to penetrate the educational space of the Polish pre-school.

\section{References}

Bogdanko A., Kowolik P. (2007) Polskie Towarzystwo Badań nad Dziećmi (powstanie, zadania, funkcje i działalność), "Nauczyciel i Szkoła”, 1-2: 20-32.

Bogdanowiczowa Z. (1928a) Znaczenie metody Montessori, "Wychowanie Przedszkolne", 6: 121-124.

Bogdanowiczowa Z. (1928b) Znaczenie metody Montessori, "Wychowanie Przedszkolne", 7/8: 145-149. 
Cicimirska N. (1928) Moja ochronka. Podręcznik metodyczny. Zbiór pogadanek i pieśni, Lwów-Warszawa, Nakładem Księgarni Gubrynowicza i Syna.

Czerwiński S. (1929/1930) Ramy programowe nauczania w państwowych seminariach ochroniarskich, "Zagadnienia Przedszkolne", 9: 6-10.

Ćwiczenie zmysłów (1925a) “Wychowanie Przedszkolne”, 10: 29-30.

Ćwiczenie zmysłów (1925b) “Wychowanie Przedszkolne”, 11-12: 39.

Darewska A. M. (1925) O ćwiczeniu zmysłów, “Wychowanie Przedszkolne”, 8-9: 24-25.

Drynda D. (2000) Geneza Nowego Wychowania w Polsce in: Galicja i jej dziedzictwo, vol. 14, Cz. Majorek, A. Meissner (eds.), Rzeszów, Wydawnictwo Wyższej Szkoły Pedagogicznej: 36 .

Gawin M. (2014) Bilet do nowoczesności. O kulturze polskiej w XIX/XX wieku, Warszawa, Teologia Polityczna.

Gustowiczówna A. (1918) System wychowawczy Dr Maryi Montessori, "Czasopismo Pedagogiczne", 1-3: 176-212.

Guz S. (ed.) (1994) Metoda Marii Montessori. Historia i współczesność, Lublin, Wydawnictwo UMCS.

Hessen S. (1935/1936) Pedagogika M. Montessori i jej losy, "Przedszkole”, 3-5.

Hessen S. (1997a) O sprzecznościach i jedności wychowania, Warszawa, Wydawnictwo Akademickie "Żak".

Hessen S. (1997b) Podstawy pedagogiki, Warszawa, Wydawnictwo Akademickie "Żak".

Jamrożek W. (2011) Kongresy pedagogiczne w rozwoju myśli i praktyki edukacyjnej w II Rzeczypospolitej in: W kręgu dorobku edukacyjnego II Rzeczypospolitej, K. Jakubiak, T. Maliszewski (eds.), Kraków, Oficyna Wydawnicza “Impuls": 15-28.

Kabzińska Ł. (2002) Dziecko jako przedmiot poszukiwań badawczych w myśli pedagogicznej przełomu XIX/XX wieku in: Dziecko w rodzinie i społeczeństwie. Dzieje nowożytne, vol. II, eds. K. Jakubiak, W. Jamrożek, Bydgoszcz, Wydawnictwo Akademii Bydgoskiej im. Kazimierza Wielkiego: 21-49.

Korzeniowska W. (2011) Myśl pedagogiczna na przestrzeni wieków. Chronologiczny słownik biograficzny, Kraków, Oficyna Wydawnicza "Impuls". 
Kupisiewicz Cz. (1984) Podstawy dydaktyki ogólnej, Warszawa, PWN.

Kupisiewicz Cz. (2012) Z dziejów teorii i praktyki wychowania. Podręcznik akademicki, Kraków, Oficyna Wydawnicza “Impuls".

Łatacz E. (1995a) Jak wychowywać dzieci? Zarys teorii pedagogicznej Marii Montessori, Warszawa, Pracownia AA.

Łatacz E. (1995b) Życie i działalność pedagogiczna Marii Montessori po roku 1910, "Acta Universitatis Lodziensis, Folia Paedagogica et Psychologica", 35: 45-61.

Łatacz E. (1996) Recepcja teorii pedagogicznej Marii Montessori w Polsce do roku 1939, Łódź, Wydawnictwo Uniwersytetu Łódzkiego.

Mackiewiczówna N. (1926) Ćwiczenia zmysłów, “Wychowanie Przedszkolne”, 2: 11-12.

Marciszewska-Posadzowa S. (1924) Z metodyki wychowania przedszkolnego, Poznań -Warszawa-Wilno-Lublin, Księgarnia św. Wojciecha.

Miąso J. (ed.) (1980) Historia wychowania: wiek XX, t. 1, Warszawa, PWN.

Międzynarodowy Kongres Nowego Wychowania w Nicei (1932) "Wychowanie Przedszkolne", 6: 170-173.

Miksza M. (2010) Zrozumieć Montessori, czyli Maria Montessori o wychowaniu dziecka, Kraków, Oficyna Wydawnicza “Impuls”.

Montessori M. (2005) Domy Dziecięce. Metoda pedagogiki naukowej stosowana w wychowaniu najmłodszych dzieci, Warszawa, Wydawnictwo Akademickie "Żak” [publication on the basis of an Italian language copy 1913].

Montessori M. (2014) Odkrycie dziecka, Łódź, transl. by Aleksandra Pluta, Wydawnictwo Palatum [original published in Italian 1948].

Od Redakcji (1926) “Wychowanie Przedszkolne”, 1: 1.

Pawłowska J. (1935/1936a) Z życia przedszkoli. Ankieta w sprawie postępów dzieci szkolnych, które otrzymały wychowanie przedszkolne, "Przedszkole", 8-9: 198-199.

Pawłowska J. (1935/1936b) Z życia przedszkoli. Przedszkole i dom, wzajemne oddziaływanie oraz wpływy, Cz. I, "Przedszkole”, 6: 135-138.

Pawłowska J. (1935/1936c) Z życia przedszkoli. Przedszkole i dom, wzajemne oddziaływanie oraz wpływy, Cz. II, “Przedszkole”, 7: 162-166. 
Pinesowa F. (1931) System wychowawczy dr Marji Montessori, Warszawa, Dom Książki Polskiej.

Prace samorzq̨du łódzkiego na polu oświaty i kultury (1931) “Dziennik Zarządu Miasta Łodzi", 35: 668.

Samsel A. (2003) Wychowanie przedszkolne w latach 1918-1939 (część II), "Wychowanie w Przedszkolu", 9: 519-523.

Schätzel I. M. (1919) Idea wychowania przedszkolnego. Casa dei Bambini jako szkółka wszechstronnej pracy dziecka, Lwów, Polskie Towarzystwo Pedagogiczne.

Sobczak J. (1998) "Nowe Wychowanie" w polskiej pedagogice okresu Drugiej Rzeczpospolitej 1918-1939, Bydgoszcz, Wyższa Szkoła Pedagogiczna.

Sosnowska J. (2014) Instytucje wychowania przedszkolnego $w$ wielokulturowej Łodzi $w$ latach 1924-1939. Organizacja, zadania, formy działania, "Wychowanie w Rodzinie", IX.: 281-306.

Sosnowska J. (2016a) Janina Pawłowska (1895-1972) i jej koncepcja wychowania oraz opieki nad dziećmi w międzywojennej Łodzi in: Obywatelki na obcasach. Kobiety $w$ życiu publicznym (XIX-XXI w.) Vol. I, U. Kozłowska, T. Sikorski (eds.), A. Wątor, Radzymin-Warszawa, Wydawnictwo von borowiecky: 281-297.

Sosnowska J. (2016b) Wydawcy polskich czasopism pedagogicznych adresowanych do wychowawczyń przedszkoli $i$ ich rola $w$ popularyzowaniu idei wychowania przedszkolnego w II Rzeczypospolitej in: Oświatowe i edukacyjne aspekty działalności wydawniczej w XX i pierwszych latach XXI wieku, I. Michalska i G. Michalski (eds.), Łódź, Wydawnictwo Uniwersytetu Łódzkiego: 31-55.

Sośnicki K. (1967) Rozwój pedagogiki zachodniej na przełomie XIX i XX wieku, Warszawa, Państwowe Zakłady Wydawnictw Szkolnych.

Sprawozdanie z Wystawy "Wychowanie Przedszkolne” (1926), "Wychowanie Przedszkolne", 5: 11-14.

Strzemeska J., Weryho M. (1920) Metoda wychowania przedszkolnego. Podręcznik dla wychowawców, Poznań-Lublin-Łódź, Wydawnictwo M. Arcta w Warszawie.

Surma B. (2008) Pedagogika Montessori - podstawy teoretyczne i twórcze inspiracje w praktyce, Łódź, Wydawnictwo Palatum.

Śliwerski B (2006) Pedagogika. Podstawy nauk o wychowaniu, t. 1, Gdańsk, Gdańskie Wydawnictwo Psychologiczne. 
Śliwerski B. (2007) Pedagogika dziecka. Studium pajdocentryzmu, Gdańsk, Gdańskie Wydawnictwo Psychologiczne.

Uklejska M. (1932) Zagadnienie pracy $w$ wychowaniu przedszkolnem, "Wychowanie Przedszkolne", 1: 1-6.

Weryho-Radziwiłłowiczowa M. (1931) Metoda wychowania przedszkolnego. Podręcznik dla wychowawców, Lwów-Warszawa, Wydawnictwo Książnica-Atlas.

Winiarzowa A. (1918) Pierwsze lata polskiego dziecka, "Ruch Pedagogiczny", 8-10: 184.

Wróbel M. (1967) Wychowanie przedszkolne w Polsce w latach 1918-1939, Wrocław -Warszawa-Kraków, Zakład Narodowy im. Ossolińskich, Wydawnictwo PAN.

W. S. (1928) Tydzień Dziecka, “Wychowanie Przedszkolne”, 10: 193-196.

Żukiewiczowa Z. (1935) Dydaktyka przedszkola, Warszawa, Nasza Księgarnia.

Żukiewiczowa Z. (1935/1936a) Fröbel i Montessori, “Przedszkole”, 5: 103-107.

Żukiewiczowa Z. (1935/1936b) Fröbel i Montessori, “Przedszkole”, 6: 126-131.

Żukiewiczowa Z. (1935/1936c) Fröbel i Montessori, "Przedszkole”, 7: 148-156.

Żukiewiczowa Z. (1935/1936d) Fröbel i Montessori, “Przedszkole”, 8/9: 175-188. 